\title{
Enhancement of Biogas Potential for Slaughterhouse Waste by Co-digestion with Animal Wastes
}

\author{
${ }^{1}$ Elijah Chebett, ${ }^{2,3}$ Ambrose Kiprop, ${ }^{1}$ Saul Namango, ${ }^{1,2}$ Milton Arimi, \\ ${ }^{1}$ Kirimi Kiriamiti and ${ }^{4}$ Y.A.C. Jande \\ ${ }^{1}$ Department of Chemical and Process Engineering, Moi University, \\ ${ }^{2}$ Africa Center of Excellence in Phytochemicals, Textile and Renewable Energy (ACEII-PTRE), Moi University, \\ ${ }^{3}$ Department of Chemistry and Biochemistry, Moi University, \\ ${ }^{4}$ Africa Center of Excellence in Water Infrastructure and Sustainable Energy Futures (WISE-Futures), Nelson Mandela African Institution \\ of Science and Technology (NM-AIST), Arusha, Tanzania
}

\section{Correspondence}

Milton Arimi, Department of

Chemical and Process Engineering,

Moi University, P.O. Box 3900, 9202,

Eldoret, Kenya, Mob.:

$+254715618243$

Received: April 16, 2020

Accepted: May 8, 2020

Published online: May 25, 2021

\begin{abstract}
The aim of the current study was to investigate biogas production from the slaughterhouse waste codigested with animal wastes. Slaughterhouses generate organic wastes that are environmentally hazardous due to high contents of biological contaminants. The use of anaerobic digestion of the slaughterhouse waste can achieve twin objectives of waste treatment and energy production as biogas. The process is however, limited by low biogas potential of slaughterhouse waste. The study evaluated the effect of codigesting the slaughterhouse, chicken and pig wastes on biogas potential. The co-digestion test with combination ratio of 1:1, slaughterhouse waste and chicken waste produced the highest value of biogas potential of $636 \mathrm{~L} / \mathrm{kg}-\mathrm{VS}$, which was almost double that from pure slaughterhouse waste. In addition, the substrate biodegradability, the biogas productivity and the yield were most improved at 1:1 co-digestion. The digestate from the process had high nutrient contents and a maximum of; $0.8,2.6$ and $2.7 \%$ of dry matter for total nitrogen, phosphate and Potassium respectively. The kinetic analysis of the codigestion process using modified Gompertz equation indicated a correlation between the waste biodegradability and biogas yield. The enhancement of the $\mathrm{C} / \mathrm{N}$ ratio in the slaughterhouse waste by co-digestion with these wastes could be responsible for the improvement of the biogas production and yield. Future studies should focus on how the nutrient rich digestate can be appropriately applied as bio-fertilizer and on how co-digestion affects the pathogens in slaughterhouse wastes.
\end{abstract}

Keywords: Anaerobic digestion, biodegradability, biogas yield, biomethane, Gompertz equation, slaughterhouse waste

(C) The Author(s) 2020. This article is licensed under a Creative Commons Attribution 4.0 International License, which permits use, sharing, adaptation, distribution and reproduction in any medium or format, as long as you give appropriate credit to the original author(s) and the source, provide a link to the Creative Commons license, and indicate if changes were made. The images or other third-party material in this article are included in the article's Creative Commons license, unless indicated otherwise in a credit line to the material. If material is not included in the article's Creative Commons license and your intended use is not permitted by statutory regulation or exceeds the permitted use, you will need to obtain permission directly from the copyright holder. To view a copy of this license, visit http://creativecommons.org/ licenses/by/4.0/. 


\section{INTRODUCTION}

The global energy demand has been increasing rapidly in response to economic expansion since the beginning of industrial revolution. As a consequence, one of the major challenges faced by many developing countries is meeting the increasing energy demand. To address this increasing demand, a lot of effort has been invested in production of renewable energy. Numerous ideas have been considered to develop alternative energy sources such as the wind, solar and biogas production. Biogas is a known renewable energy gas obtained from anaerobic digestion of organic materials from animals, agricultural wastes and other biomass materials. All these biogas substrates have organic matter that is produced from atmospheric carbon by plants. It has been pointed out that the production of bio-methane has shaped the prospective of anaerobic digestion within the context of energy security and global warming (Surroop et al., 2019; Nguyen, 2014). Other reports have indicated that biogas could replace approximately $20-30 \%$ of the world natural gas consumption (Khanal, 2011).

The slaughterhouse waste is a high strength wastewater containing more than $25 \%$ suspended organics solids (Musa et al., 2018). The effluent is fairly biodegradable with $\mathrm{BOD}_{5} / \mathrm{COD}$ ratio of around 0.5 . It has a high organic load with COD $>20 \mathrm{~g} / \mathrm{L}$ and as a result the treated effluent has high remnant COD (Musa et al., 2018; Sunder and Satyanarayan, 2013). The suspended materials contain particles like blood cells, fats, oils, fecal matter and microbes. The composition of this wastewater varies depending on other materials that are added to the stream after slaughter but it is generally rich in protein. A protein composition of $75 \%$ COD was reported with $5.5 \%$ fat (Ruiz et al., 1997). The wastewater from slaughterhouses contains many microorganisms and pathogens like coliforms. A slaughterhouse effluent reported about $1.5 \times 105$ and $7.5 \times 105 \mathrm{MPN} / 100 \mathrm{~mL}$ Fecal coliforms and Fecal enteroccus respectively (Nacheva et al., 2011). The wastewater may also contain other pathogens which can cause diseases like Tuberculosis, Helminthosis and Salmonellosis (Sunder and Satyanarayan, 2013). The restrictions from environment regulation bodies due to high COD and presence of biological contaminants necessitates pretreatment of the effluent before its disposal on soils and water bodies. The high protein contents in the effluent can be separated, treated so that it is used ingredient for formulation of animal feed especially for chicken and pigs (Gómez-Juárez et al., 1999). There are also reports of using the wastewater in cultivation of algal biofuel (Hernández et al., 2016), soil application (Bustillo-Lecompte and Mehrvar, 2015). It is also possible to screen, settle and collect blood and separate the fat from the other wastes (BustilloLecompte and Mehrvar, 2015).
Slaughterhouse waste can be used as a feedstock resource to produce biogas and organic fertilizer. The digestion of slaughterhouse waste by anaerobic process has three advantages: treatment of the waste and generation of biogas which is useful as alternative renewable energy and digestate residue useful as organic fertilizer. In anaerobic digestion, the organic materials in slaughterhouse waste are converted by bacteria into biogas through four major stages: hydrolysis, acidogenesis, acetogenesis and methanogenesis. After hydrolysis, the organic acids are converted into acetic acid in the acetogenesis stage and finally acetic acid is converted to methane $\left(\mathrm{CH}_{4}\right)$ and carbon dioxide $\left(\mathrm{CO}_{2}\right)$, the two main component of biogas, in the methanogenesis stage (Budiyono and Sumardiono, 2013; Kannan, 2000).

In spite of this potential use as feedstock resource, slaughterhouses in most developing countries is disposed as waste (Roy et al., 2013). This poses great risks of environmental pollution and health hazards because of its composition which includes; cells, pathogens and biological wastes. The main reason slaughterhouse wastes are not reused for different purposes like protein recovery is in developing countries is the costs involved (Roy et al., 2013). A suitable way and a cheap to utilize slaughterhouse wastes in these countries is by production of biogas. However, the high protein contents in the slaughterhouse waste is a limitation to effective utilization of the wastewater for biogas production (Gómez-Juárez et al., 1999).

One way of determining the suitability of a substrate to produce biogas is to calculate its biogas potential (Angelidaki et al., 2009). Previous studies indicate that co-digestion of slaughterhouse waste with fruit wastes improved biogas potential (Alvarez and Liden, 2008). It has also been reported that the rate of biogas production and the quality of biogas from donkey-dung is improved by co-digesting with various feedstock materials (Kannan, 2000).

The slaughterhouse waste is rich in nitrogen but poor in carbon source. The pig waste and chicken wastes are rich in carbon due to droppings from their feed. The co-digestion of slaughterhouse waste and the animal wastes improves the carbon to nitrogen ratio so that the biogas yield and production rate are increased. The use of kinetic models has been used to explain biogas production from various substrates. Budiyono and Sumardiono (2013) documented the Kinetic Models for biogas production rate and bio-methane potential of organic material in anaerobic digestion (Budiyono and Sumardiono, 2013). Majority of these models used modified Gompertz equation to predict the Biogas production. This study applied the modified Gompertz equation as a Kinetic Model for study of Biogas production in batch anaerobic system. The objective of this study was to evaluate the effect of co-digesting the 
slaughterhouse, chicken and pig wastes on biogas potential and biodegradability of the waste.

\section{MATERIALS AND METHODS}

Feedstock and inoculum: The feedstock samples used were Slaughterhouse Waste (SHW), Chicken Waste (CW) and Pig Waste (PW) obtained from Eldoret slaughterhouse and Eldoret Nation Polytechnic farm located in Eldoret town, Kenya. The slaughterhouse waste was obtained from fresh slaughter of cattle and consisted mainly of rumen materials and blood. The chicken waste included manure and traces of bedding materials while the pig waste included feces and urine. The sludge of digestate from operational biogas digester utilizing cow manure as substrate was used as inoculum.

Preparation of the substrates: Feedstock combination ratios of 1:1, 3:2, 3:1 (SHW: CW or PW) and 2:1:1, 3:1:1, 6:1:1 (SHW: CW: PW) were prepared for codigestion in batch anaerobic digesters. The ratios were calculated on dry sample basis.

Chemical analysis of the substrate feed: The Total Solids (\%TS) were determined using standard procedures where the samples were weighed and dried in aluminium dishes at $105^{\circ} \mathrm{C}$ in an oven furnace for 24 $\mathrm{h}$ then cooled in a desiccator.

The Total Volatile Solids (\%TVS) were determined from samples dried at $105^{\circ} \mathrm{C}$ for $24 \mathrm{~h}$. They were ground then weighed and placed in a weighed crucible where their weight was measured before calcination at $550^{\circ} \mathrm{C}$ in a muffle furnace for $4 \mathrm{~h}$. The BOD of the fresh feedstock samples was determined within $4 \mathrm{~h}$ of sample collection using the standard analytical procedures for wastewater in a BOD incubator Model TB $325 \mathrm{~S} / \mathrm{G}$ with temperature range: 5 to $60^{\circ} \mathrm{C}$; temperature accuracy: $\pm 0.2^{\circ} \mathrm{C}$; and temperature uniformity: $\pm 0.2^{\circ} \mathrm{C}$. The determination of total phosphorus was done by first digesting and reducing the phosphorus present in the waste into the free ortho-Phosphate (SRP) using persulphate digestion. After digesting in the autoclave, TP measured as $\mathrm{PO}_{4}-\mathrm{P}$ and TN was measured at $540 \mathrm{~nm}$ in quartz cuvette using UV spectrophotometer ModelUvmini-1240, 220-240 V, 50/60 Hz, made in Japan by Shimadzu Corporation.

Nitrate-nitrogen was determined using the sodiumsalicylate method with standard solutions of the nitrate prepared for the standard calibration curve. Fresh sodium salicylate solution was used in each determination. Absorbance was read and the value subtracted from the sample values for the colour correction. The nitritenitrogen determination was carried out using the reaction between sulphanilamide and N-Naphthyl-(1)ethylendiamin-dihydrochlorid which gave an intense pink colour with the nitrite. The absorbance was read from the UV spectrophotometer at a wavelength of 543 $\mathrm{nm}$.

The Total Carbon (TC), Total Nitrogen (TN), Total Phosphorous (TP) and Potassium (K) content were determined on the dried ground samples based on standard methods used for soil quality and solid wastes characterization (Okalebo et al., 2002). The TN \& TP were determined using colorimetric method. The TC was determined using titrimetric method whereas Potassium (K) content was determined using flame photometer method.

Experimental set up: Conical flask bottles of volume $250 \mathrm{~mL}$ were used as anaerobic digesters. The bottles were plugged with rubber plugs to prevent air inflow. They were equipped with valves for biogas measurement. The anaerobic digesters were operated in batch system at $35^{\circ} \mathrm{C}$ mesophilic condition. The method used to measure the amount of biogas produced was water displacement.

Experimental design: Anaerobic digestion was performed in laboratory jars as digesters and the temperature was controlled by water bath. The tests were done in triplicate. Two hundred grams of samples which had been diluted to $8 \%$ Total Solids (TS) were charged into the digesters. Ten percent inoculum, $\% \mathrm{w} / \mathrm{w}$ was added to the digesters. The inoculum added was fresh cow dung which was meant to increase methanogenic bacteria in the digesters. The variables in this study were as shown in Table 1.

The feed substrate was digested at $35^{\circ} \mathrm{C}$ for a retention period of 48 days. The biogas produced was measured daily to determine biogas production in each digester using water displacement method.

\section{Theory:}

Kinetic model of biogas production: The biodegradability of the feed materials was analysed and evaluated using the Kinetic Model of Biodegradability of organic materials based on first order reaction as expressed in Eq. (1) developed by Budiyono and Sumardiono (2013). It assumes that the kinetics of biogas production in batch condition corresponds to the specific growth rate of methanogenic bacteria in the digester:

$$
\frac{1}{t} \ln \frac{d y(t)}{d t}=\frac{1}{t}\left(\ln y_{m} k\right)-k
$$

This equation represents a straight line equation $y=$ $m x+c$ where $y=\frac{1}{t} \ln \left(\frac{d y_{t}}{d t}\right), x=\frac{1}{t}$ and $m=\left(\ln y_{m}+\right.$ $\ln k$ ) is the slope of the straight line, $c=-k$ is the vertical intercept, $y_{m}$ is the volume of biogas formed at the maximum time ( $\mathrm{mL} / \mathrm{kg} \mathrm{COD}), y_{t}$ is the volume of biogas formed at any time ( $\mathrm{t}),-k$ is the rate constant 
Table 1: Feed combinations

\begin{tabular}{|c|c|c|c|c|c|}
\hline Variable & SHW (g wet sample) & CW (g wet sample) & PW (g wet sample) & Dilution water $(\mathrm{mL})$ & Total mass of feed $(\mathrm{g})$ \\
\hline $1(1: 0: 0)$ & 100.0 & 0.0 & 0.0 & 100.0 & 200.0 \\
\hline $1 \mathrm{~A}(1: 1)$ & 48.0 & 22.5 & 0.0 & 129.5 & 200.0 \\
\hline $1 \mathrm{~B}(1: 1)$ & 48.0 & 0.0 & 27.2 & 124.8 & 200.0 \\
\hline $1 \mathrm{C}(2: 1: 1)$ & 48.0 & 13.3 & 13.6 & 127.1 & 200.0 \\
\hline $2 \mathrm{~A}(3: 1)$ & 72.0 & 11.3 & 0.0 & 116.7 & 200.0 \\
\hline $2 \mathrm{~B}(3: 1)$ & 72.0 & 0.0 & 13.6 & 114.4 & 200.0 \\
\hline $2 \mathrm{C}(6: 1: 1)$ & 72.0 & 5.7 & 6.8 & 115.5 & 200.0 \\
\hline $3 \mathrm{~A}(3: 2)$ & 57.6 & 18.0 & 0.0 & 124.4 & 200.0 \\
\hline $3 \mathrm{~B}(3: 2)$ & 57.6 & 0.0 & 21.8 & 120.6 & 200.0 \\
\hline $3 \mathrm{C}(3: 1: 1)$ & 57.6 & 9.0 & 10.9 & 123.4 & 200.0 \\
\hline
\end{tabular}

associated with degradation of the organic materials (/day). The more negative the value of $(-k)$, the faster the rate of removal of the biodegradable fractions. Yusuf et al. (2011) reported that the more negative value of $(-k)$ obtained from first order kinetics, the more biogas production potential (A) was obtained from modified Gompertz model.

The analysis and evaluation of the biogas production of the feedstock combinations in this study was done using the Kinetic Model of Biogas production modelled through modified Gompertz Eq. (2):

$$
P=A \exp \left\{-\exp \left[\frac{U \cdot e}{A}(\lambda-t)+1\right]\right\}
$$

where,

$P \quad$ : The cumulative of specific biogas production ( $\mathrm{L} / \mathrm{kg}$ of sample)

$A$ : Biogas production potential (L/kg of sample)

$U$ : Maximum biogas production rate $(\mathrm{L} / \mathrm{kg}$ of sample. day)

$t$ : Cumulative time for biogas production (days)

$e \quad:$ Mathematical constant (2.718282)

$\lambda$ : Lag phase period or minimum time to produce biogas (days)

The Kinetic Constants of $A, \lambda$ and $U$ in the modified Gompertz equation for Kinetic Model of Biogas Production applied by Budiyono and Sumardiono (2013) was determined using non-linear regression with help of polymath software. The model assumed that the kinetic of biogas production from organic materials in batch fed system corresponds to the specific growth rate of methanogenic bacteria in the anaerobic digester.

\section{RESULTS AND DISCUSSION}

Substrate characterization: The substrate samples were analysed total solids, volatile solids, total nitrates, total phosphates, total carbon and potassium (Table 2).

The main limitation to biodigestion of slaughterhouse wastes lies in its composition. The SHW waste has high lipid and protein contents that are inhibitory to anaerobic digestion thus reducing the biogas production (Palatsi et al., 2011). Moreover, the high total nitrogen content in slaughterhouse wastes reduces the $\mathrm{C} / \mathrm{N}$ ratio. The data in the table indicate that the pig waste had the high $\mathrm{C} / \mathrm{N}$ ratio of 15:1. This is in agreement with studies by Teglia et al. (2011) who found similar range for solid digestate substrates. The low $\mathrm{C} / \mathrm{N}$ ratio of SHW obtained in this study could have been another reason for the low biodegradability. An optimal $\mathrm{C} / \mathrm{N}$ ratio of 30:1 has been reported for biodigestion (Yan et al., 2015). A possible explanation for poor biodegradability at low $\mathrm{C} / \mathrm{N}$ ratio is the shift of microbial composition in the reactor. A change which causes increase in competing microbes decreases methanogens in the reactor thereby decreasing biogas yield. Some of the competitors to methanogens in bioreactors include sulfate reducing bacteria, acetogens and the heterotrophs.

Effect of co-digestion on biogas yield, production rate and start-up time: The effect of co-digestion of SHW in varying proportions with $\mathrm{CW}$ and $\mathrm{PW}$ on biogas yield is presented in Fig. 1. The highest value of biogas yield $636 \mathrm{~L} / \mathrm{kg}$ VS sample was obtained in the sample with equal proportion of slaughterhouse waste and chicken was (1A). Previous studies reported similar biogas production yields $(620 \mathrm{~L} / \mathrm{kg} \mathrm{VS})$ for anaerobic digestion of cattle slurry mixed with cheese whey (Comino et al., 2012). The low value of biogas production for SHW can be attributed to high lignocelluloses which make it difficult to be degraded by biogas producing microorganisms. The fats and lipids delay the process of biogas formation. There is also a possibility that the high nitrogen compounds in the substrates were converted to ammonia which inhibited biodigestion. A possible method of this conversion entails denitrification of nitrates and nitrogen fixing by specialized microbes.

Generally, the co-digestion of the slaughterhouse waste was favourable when it was mixed with equal amount of the two other waste feedstocks. The biogas potential and maximum biogas production rate are given in Table 3. The samples; $1 \mathrm{~A}, 1 \mathrm{~B}$ and $3 \mathrm{~A}$ resulted in higher biogas potential of 636,563 and $548 \mathrm{~L} / \mathrm{kg}$ VS respectively. The enhancement of biogas potential by codigestion of SHW with animal wastes is possibly due to increased amount of carbohydrates which increases it $\mathrm{C} / \mathrm{N}$ ratio. These compounds are more appropriate for degradation by the biogas producing micro-organisms compared to SHW alone. The feed ratio with high 


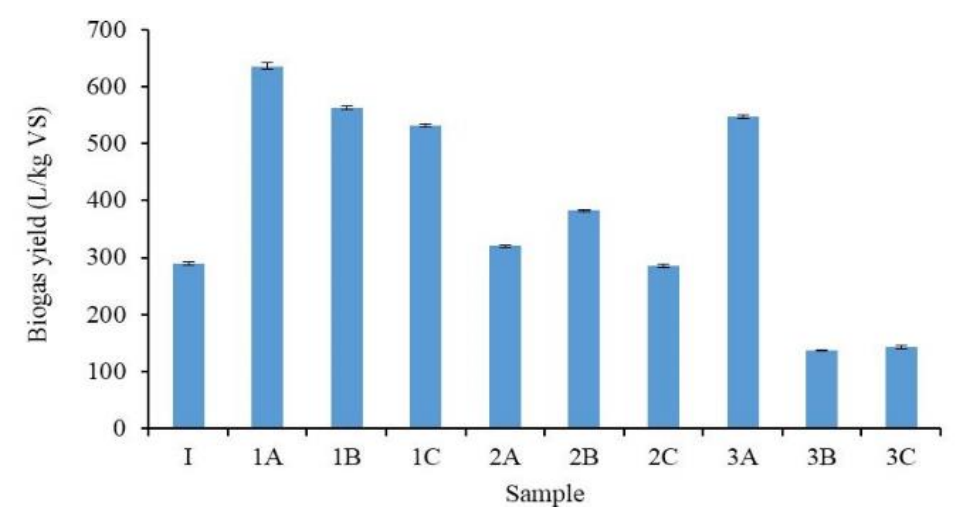

Fig. 1: The biogas yields of various samples tested

1: $100 \%$ SHW; 1A: $1: 1$ SHW to CW; 1B: $1: 1$ SHW to PW; 1C: $2: 1: 1$ SHW to CW to PW; $2 \mathrm{~A}: 3: 1$ SHW to CW; $2 \mathrm{~B}: 3: 1$ SHW to PW; 2C: 6:1:1 SHW to CW to PW; 3A: 3:2 SHW to CW; 3B: 3:2 SHW to PW; 3C: 3:1:1 SHW to CW to PW; SHW: Slaughterhouse waste; CW: Chicken waste; PW: Pig waste

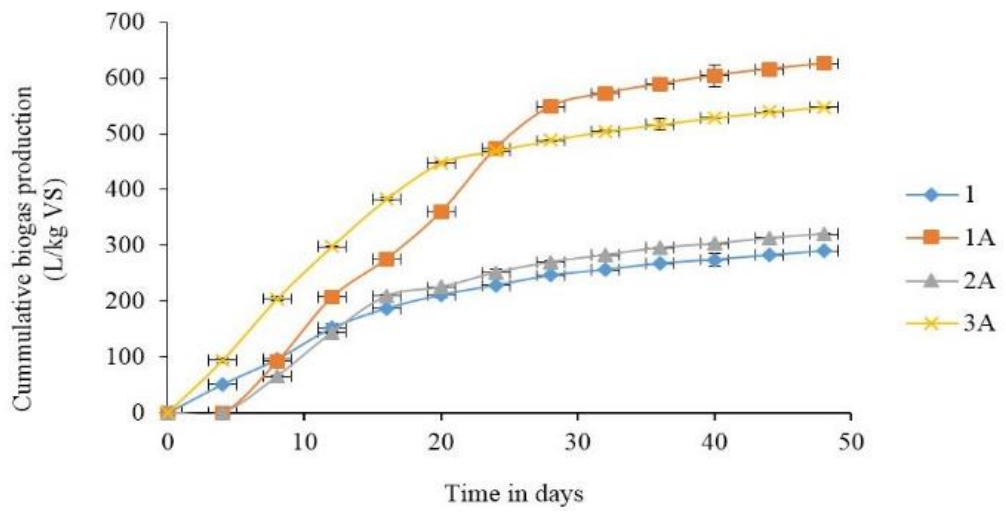

Fig. 2: Biogas production curves for slaughterhouse waste co-digestion with chicken waste

1: 100\% SHW; 1A: 1:1 SHW to CW; 2A: 3:1 SHW to CW; 3A: 3:2 SHW to CW; SHW: Slaughterhouse waste; CW: Chicken waste

Table 2: The properties of the feed material used

\begin{tabular}{|c|c|c|c|}
\hline \multirow[b]{2}{*}{ Parameters } & \multicolumn{3}{|c|}{ Feedstock material } \\
\hline & SHW & $\mathrm{CW}$ & PW \\
\hline TS $(\% \mathrm{w} / \mathrm{w})$ & 16.170 & 35.510 & 29.390 \\
\hline VS (\%w/w TS) & 77.960 & 75.310 & 77.150 \\
\hline $\mathrm{TN}(\% \mathrm{DM})$ & 2.210 & 2.778 & 1.802 \\
\hline TP (\% DM) & 0.569 & 0.830 & 1.236 \\
\hline $\mathrm{K}(\% \mathrm{DM})$ & 1.010 & 0.570 & 0.450 \\
\hline TC (\% DM) & 16.920 & 28.800 & 27.120 \\
\hline $\mathrm{C} / \mathrm{N}$ ratio & $8: 1$ & $10: 1$ & $15: 1$ \\
\hline
\end{tabular}

TS: Total solids; VS: Volatile solids; TN: Total nitrogen; DM: Dry matter; TP: Total phosphorus; TC: Total carbon

Table 3: Performance of different substrate feed ration on biogas potential, biogas production rate and start-up time requirement

\begin{tabular}{llll}
\hline Sample & Biogas potential, A (L/kg-VS) & Max. biogas production rate, U (L/kg-VS.day) & Min. time for biogas production, $\lambda$ in days \\
\hline 1 & 290 & 23 & 0 \\
1A & 636 & 45 & 0 \\
1B & 563 & 41 & 0 \\
1C & 532 & 38 & 0 \\
2A & 320 & 25 & 4 \\
2B & 382 & 27 & 0 \\
2C & 286 & 27 & 7 \\
3A & 548 & 40 & 0 \\
\hline
\end{tabular}

1: Pure SHW; 1A: 1:1 SHW to CW; 1B: 1:1 SHW to PW; 1C: 2:1:1 SHW to CW to PW; 2A: 3:1 SHW to CW; 2B: 3:1 SHW to PW; 2C: 6:1:1 SHW to CW to PW; 3A: 3:2 SHW to CW; SHW: Slaughterhouse waste; CW: Chicken waste; PW: Pig waste; Max.: Maximum; Min.: Minimum 


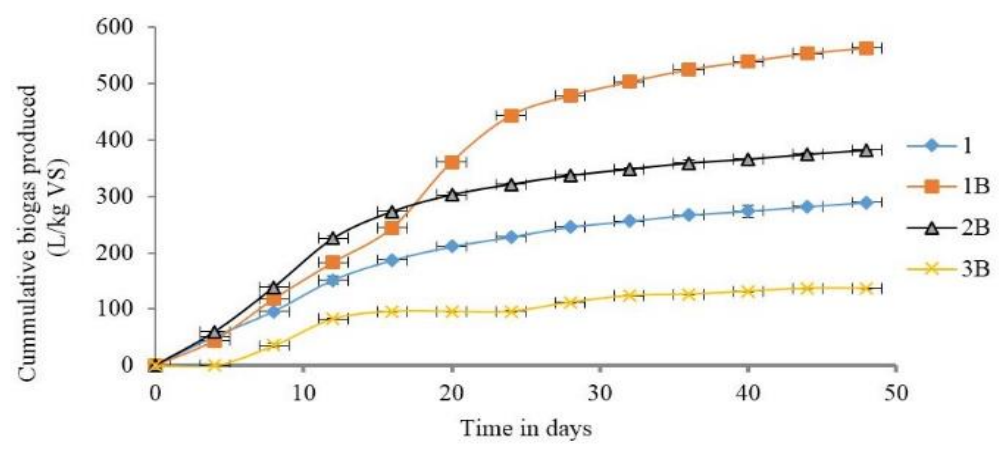

Fig. 3: Biogas production curves for slaughterhouse waste co-digestion with pig waste 1: 100\% SHW; 1B: 1:1SHW to PW; 2B: 3:1 SHW to PW; 3B: 3:2 SHW to PW; SHW: Slaughterhouse waste; PW: Pig waste

slaughterhouse content like $2 \mathrm{~A}, 2 \mathrm{~B}$ and $2 \mathrm{C}$, resulted in low biogas potential and biogas production rate. This implies that increasing the co-digestion material may not necessarily improve the anaerobic process.

The startup time is an important parameter in batch anaerobic processes. The results of start-up tests indicate that the highest time taken to form biogas, $\lambda$ was 7 days. This could be the time the biogas producing microorganisms took to adjust to the digester conditions. The pure SHW sample had very short start-up time with biogas production starting within a day. This could be explained by the fact that SHW is semi-liquid in nature compared to the two solid wastes that were used for codigestion. The solid particles must first be broken into simpler compounds before bio-methanation takes place. The co-digestion of the slaughterhouse and either type of waste at 1:1 ratio can drastically reduce the start-up time for bio-digestion of these wastes.

Slaughterhouse waste co-digestion with chicken waste: The cumulative biogas production curves for codigestion of SHW with $\mathrm{CW}$ are as shown in Fig. 2. The highest quantity of biogas was produced in digester bottle $1 \mathrm{~A}$ with feed combination ratio of $1: 1$. Table 2 shows that $\mathrm{CW}$ and $\mathrm{SHW}$ have $\mathrm{C} / \mathrm{N}$ ratio of $10: 1$ and $8: 1$ respectively which is lower than 20:1 proposed by other researchers (Teglia et al., 2011). The commercial feed of chicken contains simpler carbohydrates than SHW and thus substrates provided by this combination ratio of $1: 1$ favored growth of biogas producing bacteria resulting in higher biogas production rate and total amount of biogas produced. All the three feed combination ratios of $1: 1$, 3:2 and 3:1 gave higher biogas production compared to digestion of SHW alone. It took a minimum of 4 days for biogas to be produced from the digestion of feed mixture with ratio $3: 1$. This indicates that the microorganisms took some time adjusting to digester conditions. However, the activity as suggested by biogas production after adjustment was higher rate than SHW alone. For the first 18 days, the rate of biogas production from digestion mixture ratios of $1: 1$ and $3: 2$ was almost the same. The higher rate of biogas production after eighteen days by $1 \mathrm{~A}$ may be due to the higher proportion of chicken waste in that mixture.

Overproduction of ammonia is one of the causes of inhibition to bio-methanation of protein rich substrates like slaughterhouse (Kayhanian, 1994). In the study, very low biogas production was recorded when using pure slaughterhouse wastes from $12^{\text {th }}$ day. This could be attributed to production of inhibitory substances; possibly ammonia. The presence of the inhibitor makes microorganisms remain dormant during the intermittent periods as they adjust to the toxic environment. After this the microbes enter the death phase where biogas production stops completely.

Slaughterhouse waste co-digestion with pig waste: The cumulative biogas production curves for codigestion of slaughterhouse waste with pig waste whereas shown in Fig. 3. The highest quantity of biogas was produced in digester bottle 1B with feed combination ratio of $1: 1$. The feed combination ratio $3: 1$ (2B) gave slightly higher biogas production than pure slaughterhouse waste. However, the feed combination ratio of 3:2 (3B) produced significantly lower biogas than slaughterhouse waste digested alone. The findings show that when slaughterhouse waste was combined with pig waste in the proportion of $3: 2$, biogas producing microorganisms took up to 6 days to adjust to the conditions in the digester thereby delaying biogas production.

The results also indicate that microbial activity was inhibited from $16^{\text {th }}$ day in most feed samples leading to decreased biogas production. This was eventually followed by stoppage of biogas production from $42^{\text {nd }}$ day of digestion. The microorganisms remained dormant during the intermittent periods as they adjusted to the new biochemical environment produced by fermentation process. The graph of biogas production indicates a two 
phase process. The two phases are possibly caused by a shift in the composition of microbes involved in biogas production. A similar observation has been reported where methanobacterium shifted to methanoculleus in solid state anaerobic digestion (Yan et al., 2015).

Slaughterhouse waste co-digestion with chicken \& pig wastes: The cumulative biogas production curves for co-digestion of slaughterhouse waste with chicken and pig wastes are as shown in Fig. 4. The highest quantity of biogas was produced in digester bottle $1 \mathrm{C}$ with feed combination proportion of $2: 1: 1$. This indicated that the substrates provided by this combination favored growth of biogas producing microorganisms. The biogas production rate and yield in $1 \mathrm{C}$ was comparable to that produced in digester feed ratios $1 \mathrm{~A}, 1 \mathrm{~B}$ which produced high performance. In all three sample tests, SHW was mixed with the rest of wastes at 1:1 as optimal ratio for its co-digestion. The feed combination proportion of $6: 1: 1$ (2C) yielded almost the same amount of biogas as pure slaughterhouse waste. However, biogas production started after 7 days of batch feeding in $2 \mathrm{C}$ samples. The feed combination ratio of $3: 1: 1$ (3C) produced significantly lower amount of biogas than the pure

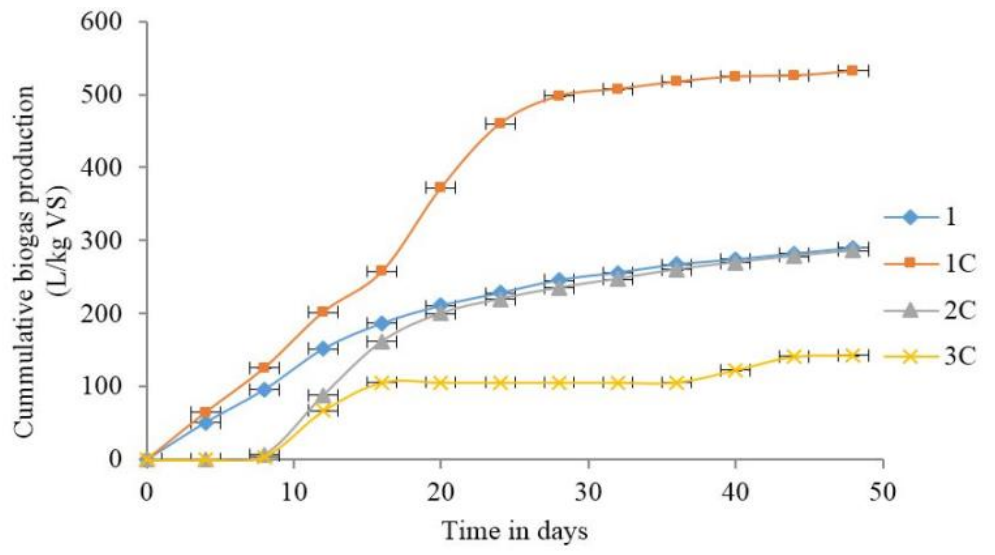

Fig. 4: Biogas production curves for co-digestion of slaughterhouse waste with chicken and pig wastes 1: 100\% SHW; 1C: 2:1:1 SHW to CW to PW; 2C: 6:1:1 SHW to CW to PW; 3C: 3:1:1 SHW to CW to PW; SHW: Slaughterhouse waste; CW: Chicken waste; PW: Pig waste
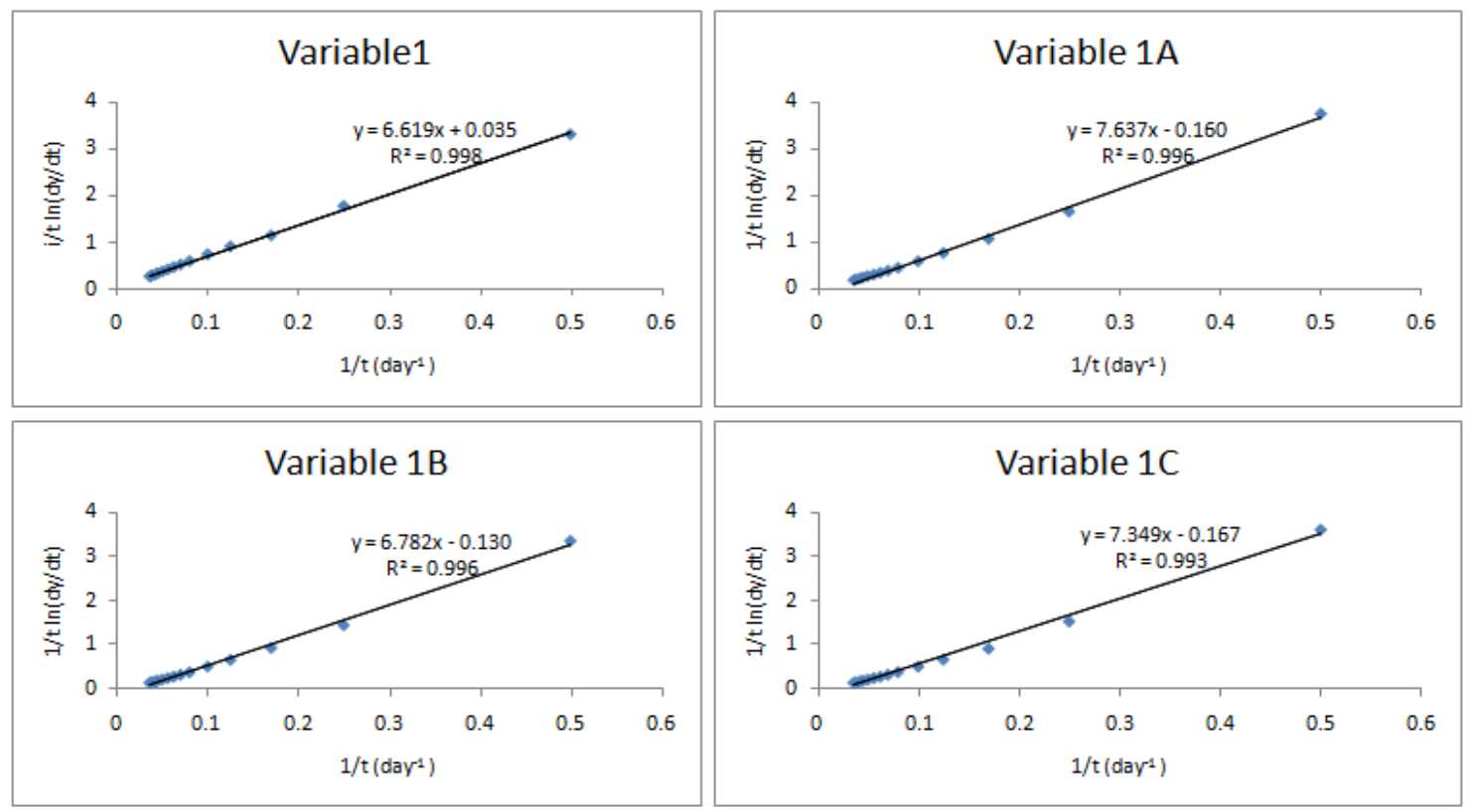

Fig. 5: Biodegradability plots of the sample tested

1: $100 \%$ SHW; 1C: 2:1:1 SHW to CW to PW; 1A: 1:1 SHW to CW; 1B: 1:1 SHW to PW; 1C: 2:1:1 SHW to CW; SHW: Slaughterhouse waste; CW: Chicken waste; PW: Pig waste; 171: 100\% SHW 
slaughterhouse waste sample. This feed combination had similar effect with 3:2 (3B) where the biogas producing microorganisms took up to 7 days to adjust to the environment before producing biogas.

Kinetic model of biodegradability for co-digestion: The kinetic model of biodegradability of organic materials used for analysis and evaluation in this study used equation 1 which had previously been used by other researchers (Budiyono and Sumardiono, 2013; Yusuf et al., 2011). The equation assumes first order kinetics. It has been pointed out that the more negative the value of (-k), the faster the rate of degradation of the organic matter (Yusuf et al., 2011). The rate of biodegradability of biomass is associated with how easy or hard it is for the microorganisms to work on the organic matter. The values of $(-\mathrm{k})$ obtained by plotting the data determined from Eq. (1) based on the experimental results for the various variables in this study are as shown in Fig. 5.

The results indicate that the sample with equal amount of slaughterhouse waste and chicken waste (1A) and the one with slaughterhouse waste added half the amount of chicken waste and pig waste (1C) had the highest biodegradability because of high negative value of $\mathrm{k}$. The pure slaughterhouse sample had the least biodegradability due to the positive value of $\mathrm{k}$. The results support those for biogas potential, production rate and biogas yield which indicated $1 \mathrm{~A}$ and $1 \mathrm{C}$ as best performing samples.

The results of the studies on biogas yields and kinetics of waste biodegradation indicate a correlation between; substrate biodegradability, biogas yields and biogas potential. This is in agreement with another study where a correlation between waste biodegradability and methane production was reported before membrane treatment of slaughterhouse waste (Jensen et al., 2015). The results from the study also indicate that chicken waste was a better material for co-digestion with the slaughterhouse waste in all parameters tested. However, a different study with pure substrates indicated that swine waste was better substrate for bio-methane production compared to chicken and cow wastes (Ahn et al., 2010). From the current study, the samples with high proportion of chicken wastes had low biogas yields and potential compared to one with equal proportion (1A). This indicates that co-digestion had possibly improved the digestion of chicken wastes.

One possible application of the digestate of slaughterhouse waste treatment is in agriculture to cultivate various crops (Asses et al., 2019; Roy et al., 2013). This study found that the slaughterhouse waste has high contents of minerals like nitrogen, phosphorous and potassium which are all essential for plant growth. However, the presence of pathogens (Franke-Whittle and Insam, 2013) and heavy metals (González-González et al., 2014) remains a great challenge to its application. The process of anaerobic digestion minimizes the pathogens hence making the digestate safer for application. Further research on how co-digestion of the slaughterhouse wastes with other animal wastes affects the pathogens in the final digestate should be carried out.

\section{CONCLUSION}

The biogas potential of slaughterhouse waste after co-digestion with chicken and pig wastes was investigated. The kinetic model of waste degradation was also tested using modified Gompertz equation. The results indicated that slaughterhouse waste has low $\mathrm{C} / \mathrm{N}$ ratio of $8: 1$ which is probably the cause of low biodegradability. The effects on ammonia formation due to co-digestion should be investigated further. The results also showed that co-digestion of slaughterhouse waste with chicken and pig wastes can enhance biogas potential of the former. The co-digestion of slaughterhouse waste with chicken waste in $1: 1$ combination ratio produced biogas yield of $636 \mathrm{~L} / \mathrm{kg}-$ VS. The same was found to enhance biogas productivity and the kinetics of substrates biodegradability. Further research needs to be carried out to evaluate the quality of the biogas produced by anaerobic co-digestion process. In addition, the scale-up studies on co-digestion should be done to ascertain the cost-effectiveness of the process. More studies on the effect of co-digestion on pathogens in the produced digestate is also required.

\section{ACKNOWLEDGMENT}

Africa Center of Excellence in Phytochemicals, Textile and Renewable Energy (ACEII-PTRE), Moi University is acknowledged for the support in facilitating the researchers in undertaking this study.

\section{REFERENCES}

Ahn, H.K., M.C. Smith, S.L. Kondrad and J.W. White, 2010. Evaluation of biogas production potential by dry anaerobic digestion of switchgrass--animal manure mixtures. Appl. Biochem. Biotech., 160: 965-975.

Alvarez, R. and G. Liden, 2008. Semi-continuous codigestion of solid slaughterhouse waste, manure and fruit and vegetable waste. Renew. Energ. 33(4): 726-34.

Angelidaki, I., M. Alves, D. Bolzonella, L. Borzacconi, I.J. Campos, J.A. Guwy, S. Kalyuzhnyi, P. Jenicek and J.B. van Lier, 2009. Defining the Biomethane Potential (BMP) of solid organic wastes and energy crops: A proposed protocol for batch assays. Water Sci. Technol., 59(5): 927-934.

Asses, N., W. Farhat, M. Hamdi and H. Bouallagui, 2019. Large scale composting of poultry slaughterhouse processing waste: Microbial removal and agricultural biofertilizer application. Process Saf. Environ., 124: 128-136. 
Budiyono, I.S. and S. Sumardiono, 2013. Biogas production kinetic from vinasse waste in batch mode anaerobic digestion. World Appl. Sci. J., 26: 1464-1472.

Bustillo-Lecompte, C.F. and M. Mehrvar, 2015. Slaughterhouse wastewater characteristics, treatment and management in the meat processing industry: A review on trends and advances. J. Environ. Manage., 161: 287-302.

Comino, E., V.A. Riggio and M. Rosso, 2012. Biogas production by anaerobic co-digestion of cattle slurry and cheese whey. Bioresource Technol., 114: 46-53.

Franke-Whittle, I.H. and H. Insam, 2013. Treatment alternatives of slaughterhouse wastes and their effect on the inactivation of different pathogens: A review. Crit. Rev. Microbiol., 39(2): 139-151.

Gómez-Juárez, C., R. Castellanos, T. Ponce-Noyola, V. Calderón and J. Figueroa, 1999. Protein recovery from slaughterhouse wastes. Bioresource Technol., 70(2): 129-133.

González-González, A., F. Cuadros, A. Ruiz-Celma and F. López-Rodríguez, 2014. Influence of heavy metals in the biomethanation of slaughterhouse waste. J. Clean. Prod., 65: 473-478.

Hernández, D., B. Riaño, M. Coca, M. Solana, A. Bertucco and M.C. García-González, 2016. Microalgae cultivation in high rate algal ponds using slaughterhouse wastewater for biofuel applications. Chem. Eng. J., 285: 449-458.

Jensen, P.D., S.D. Yap, A. Boyle-Gotla, J. Janoschka, C. Carney, M. Pidou and D.J. Batstone, 2015. Anaerobic membrane bioreactors enable high rate treatment of slaughterhouse wastewater. Biochem. Eng. J., 97: 132-141.

Kannan, N., 2000. Design, development and evaluation of biogas plant using donkey dung and selected biomaterials as feed stock. Ph.D. Thesis, University of Agricultural Sciences, Gkvk Bangalore.

Kayhanian, M., 1994. Performance of a high-solids anaerobic digestion process under various ammonia concentrations. J. Chem. Technol. Biot, 59: 349-352.

Khanal, S.K., 2011. Anaerobic Biotechnology for Bioenergy Production: Principles and Applications. John Wiley \& Sons.

Musa, M.A., S. Idrus, C.M. Hasfalina and N.N.N. Daud, 2018. Effect of organic loading rate on anaerobic digestion performance of mesophilic (UASB) reactor using cattle slaughterhouse wastewater as substrate. Int. J. Environ. Res. Pub. Health, 15(10): 2220 .
Nacheva, P.M., M.R. Pantoja, E.A. Lomelí Serrano, 2011. Treatment of slaughterhouse wastewater in upflow anaerobic sludge blanket reactor. Water Sci. Technol., 63(5): 877-884.

Nguyen, T., 2014. Bio-methane potential test for rapid assessment of anaerobic digestion of sewage sludge: Co-digestion with glycerol and trace organic removal. M.Phil. Thesis, University of Wollongong, United Arab Emirates.

Okalebo, J.R., K.W. Gathua and P.L. Woomer, 2002. Laboratory Methods of Soil and Plant Analysis: A Working Manual. 2nd Edn., Sacred Africa, Nairobi, pp: 21.

Palatsi, J., M. Viñas, M. Guivernau, B. Fernandez and X. Flotats, 2011. Anaerobic digestion of slaughterhouse waste: Main process limitations and microbial community interactions. Bioresource Technol., 102(3): 2219-2227.

Roy, M., S. Karmakar, A. Debsarcar, P.K. Sen and J. Mukherjee, 2013. Application of rural slaughterhouse waste as an organic fertilizer for pot cultivation of solanaceous vegetables in India. Int. J. Recycl. Organ. Waste Agric., 2(1).

Ruiz, I., M.C. Veiga, P. De Santiago and R. Blazquez, 1997. Treatment of slaughterhouse wastewater in a UASB reactor and an anaerobic filter. Bioresource Technol., 60(3): 251-258.

Sunder, G.C. and S. Satyanarayan, 2013. Efficient treatment of slaughter house wastewater by anaerobic hybrid reactor packed with special floating media. Int. J. Chem. Phys. Sci., 2: 73-81.

Surroop, D., Z.M.A. Bundhoo and P. Raghoo, 2019. Waste to energy through biogas to improve energy security and to transform Africa's energy landscape. Curr. Opin. Green Sust. Chem., 18: 79-83.

Teglia, C., A. Tremier and J.L. Martel, 2011. Characterization of solid digestates: Part 2, assessment of the quality and suitability for composting of six digested products. Waste Biomass Valor., 2(2): 113-126.

Yan, Z., Z. Song, D. Li, Y. Yuan, X. Liu and T. Zheng, 2015. The effects of initial substrate concentration, $\mathrm{C} / \mathrm{N}$ ratio and temperature on solid-state anaerobic digestion from composting rice straw. Bioresource Technol., 177: 266-273.

Yusuf, M.O.L., A. Debora and D.E. Ogheneruona, 2011. Ambient temperature kinetic assessment of biogas production from co-digestion of horse and cow dung. Res. Agr. Eng., 57(3): 97-104. 